\title{
Hybridization in Mandailing Culture: An Overview of Willem Iskander's Text Si Bulus-Bulus Si Rumbuk-Rumbuk
}

\author{
Muharrina Harahap ${ }^{1}$; Faruk; Aprinus Salam ${ }^{2}$ \\ ${ }^{1}$ Department of Indonesian Language and Literature, Medan State University, North Sumatera, Indonesia \\ ${ }^{2}$ Department of Indonesian Literature, Faculty of Cultural Sciences, Gadjah Mada University, Yogyakarta, Indonesia \\ http://dx.doi.org/10.18415/ijmmu.v6i5.1053
}

\begin{abstract}
This study examines identity issues in and among the Mandailing people, adapting Bhabha's argument that there is no stable identity, but that identity changes with every interaction in society. For this examination of identity, Bhabha's concept of hybridity has been adapted to investigate the mixture of identities among the Mandailing people.The hybridization in Mandailing is caused by several factors including: cultural contacts, Islamization, migration, and colonialism. The author uses a postcolonial review to see the process of hybrid formation in Mandailing through literary text written by a Mandailing writer, named Willem Iskander, entitled Si Bulus-Bulus Si Rumbuk-Rumbuk. The text consists of several poems and prose representing the identity of the Mandailing people in the colonial era. In order to realize the postcolonial, the author chooses a critical discourse analysis method for analyzing the data in the text. This critical analysis is able to unravel the colonial discourses that are metaphorically in the text. By combining with the postcolonial theory, especially proposed by Bhabha, this research results a finding, hybridization giving rise to the ambivalence of the Mandailing people. This ambivalence manifests in the social, cultural and political life of the people.
\end{abstract}

Keywords: Ambivalence; Identity; Colonialism; Literary; Willem Iskander

\section{Introduction}

Discussion of hybridisation is part of postcolonial studies, having been popularised by the postcolonial thinker Homi K. Bhabha in his book The Location of Culture. Initially, the term came from botany, but was adopted by Bhabha to refers to the "fusion" of different things. In this paper, hybridisation is understood (Barker 2008, 214) as a mixture of various things with hybrid characteristics, a criticism of Said's view that identity is stable. Bhabha believes that there is no single identity, but that all identities are combinations of several different things. The single identity described by Said (1994), according to Bhabha, is a colonial discourse that has been divided. Quoting Bhabha, Barker clarifies that a hybrid character can apply to an entire culture, creating zones of bulkhead change and hybridisation in 
religion, class, gender, age, and nation. Such elements, according to Barker, can be useful for explaining cultural mixing and the emergence of new forms of identity.

Such new forms of identity have emerged among the Mandailing people. In their article, Agustono and Junaidi $(2018,51)$ identify the Mandailing as living in the Tapanuli region, which is part of North Sumatra. According to these authors, colonialism in North Sumatra also began in that region. Dutch colonialism in the Mandailing part of Tapanuli transformed the region into a Dutch administrative district, and it was significantly affected, especially in terms of economy and population. This shows that Mandailing have been important since the colonial era, a factor that makes the Mandailing interesting to discuss, especially their hybridisation and ambivalence.

A discussion about Mandailing and the text of Si Bulus-Bulus Si Rumbuk-Rumbuk was conducted by Rodgers (2005). Rodgers has examined Mandailing through his article on folklore-writing, dictionary-making, and grammar-recording in school textbooks in colonial Sumatra, including Willem Iskander's work Si Bulus-Bulus Si Rumbuk-Rumbuk. Social transformation in Mandailing was successful Iskandar's initiation of a formal school system. He was able to create an image of Mandailing by publishing printed books that were as good as those in Europe, enabling the efficient transition from orality to literacy.

Rodgers has also described the Mandailing people as tracing their roots to the emergence of written scripts and formal schools in Sumatra, which were almost comparable to the formal education systems in Europe. Iskander managed to motivate the Mandailing community to study at formal schools. For his efforts, Iskander was provided a scholarship by the colonial government to deepen his knowledge in the Netherlands.

Further research Rodgers (2007) has explored the phenomenon of writing among the Batak of North Sumatra. Batak-language texts, printed in the Latin script, first emerged following Iskandar's establishment of a formal school system. The development of writing led to rapid growth in the publication of newspapers, literary works (novels etc.) in North Sumatra. For example, Batak-language fiction began to be found in Padang Sidempuan following the establishment of a formal school. When Batak fiction emerged in South Tapanuli, considerable shifts occurred in the dialects of authors, creating what many linguists have identified as a linguistic panorama. Writers used a wide range of styles, and presented various social characteristics in their literary. Rodgers refers to these colonial-era works as Indonesian colonial novels.

Lubis (2003) has also explored the processes through which tribal identity and leadership have transformed in Mandailing. He argues that the Mandailing people have undergone cultural hybridisation and creation, adopting and adapting cultural features from around the world. In the current era of globalisation, Lubis notes, there has been a strengthening of local identity, which has resulted in the rise of "imaginary communities" and formation of cultural hybridisation.

Then, Siregar, Djono, and Sutimin (2018) have also discussed the educational values in the literary text. They use a descriptive qualitative analysis in describing the character education obtained in learning related to the text contents. Furthermore, Harahap, Faruk and Salam (see Harahap et al. 2019) discuss about "Si Bulus-Bulus Si Rumbuk-Rumbuk as Hegemonic Text" in the Atavism journal 2019. The article discusses the ambivalence of the literary text in the discourse of two experts. The text is as ambivalent as the author's life. Most recently, Harahap, Faruk and Salam (see Harahap, et al. 2019) also write another article entitled "Racism in Mandailing Literature: Postcolonial Discourse" in international conference proceedings published by Syiah Kuala University Press. This article examines the literary dichotomy occurred during the colonialism in Mandailing, North Sumatra.

The study of Willem Iskander's text continues discussing the previous studies. The text is a material object of this study. The identity ambivalence occurs in Mandailing, seen through a literary work entitled Si Bulus-Bulus Si Rumbuk-Rumbuk by Willem Iskander. The text consists of 12 poems, 1 drama, and 7 prose. All of the literary genres describe the identity ambivalence of the Mandailing people. 
Harahap, et all (2019, p. 89) states that the text represents the identity of the Mandailing people. The people are those who represented in the literary text.

Data have been taken from the text based on the subject matter, and are considered to represent the Mandailing people in the colonial era. The term representation, borrowed from Hall (1997), will help us explain how the Mandailing people were framed in this literary work. Hall interprets representation as the production of meanings through language, or, more specifically, the production of meanings from the mental concepts that are realised through language. The relationship between concepts and language, according to Hall, makes it possible to refer to both real objects, people, or events, as well as imaginary ones (Hall 1997, 17).

Furthermore, the author uses a post-colonial paradigm and critical discourse analysis to study the phenomena of the text. The colonialism occurred in Mandailing have been critically examined. The analysis of the critical discourse referred to (Foucault, 1972) by analyzing the power relations formed in the text. Bhabha (1994) adopts Foucault's theory to see the power relations in the realm of colonialism. He calls it as a colonial discourse analysis (see Harahap et al., 2019, p. 93). The significance of this study contribute to the development of literary studies, particularly Mandailing literature in a post-colonial perspective.

\section{Hybridisation in Mandailing}

Before exploring hybridisation in Mandailing, it is best to discuss the development of postcolonial theory. This is important to ease the understanding of Mandailing hybridity. In this discussion, we note that hybridity had occurred even before European colonialism began in Mandailing, reflecting the view (Ashcroft, Griffiths, and Tiffin 2003) that postcolonial studies include all cultures that have experienced imperial power from the beginning of the history of colonisation to the present period. Traditionally, this continuity of "colonialism" has begun with the start of European imperial aggression.

Hybridity, thus, is interpreted here is the context built by Day and Foulcher $(2008,13)$, that is, not only considering the alloy products of culture but also the ways of placing cultural products in social and historical spaces against the coercion and rejection of power relations. This problem of hybridity is also explained by Bhabha $(1994,107)$, who writes 'the colonial presence is always ambivalent, split between its appearance as original and authoritative and its articulation as repetition and difference.' Uncertainty afflicts the discourse of power, an uncertainty that overrides known symbols of national authority that arose arisen from colonial appropriation as a sign of difference. Hybridity refers to a shift from symbols to signs that cause splits in the dominant discourse.

Hybridization discussed by the experts also applies in Mandailing. An overview of Mandailing will be explained at first before discussing hybridization in depth. This can be seen, for example, in the discussion of the Mandailing by Mpu Prapanca in the Book of Negarakertagama, which has been dated to 1365 CE. Mandailing, mentioned in the first stanza and thirteenth poem of this manuscript, is recorded as an important part of the Nusantara or nation at that time. The significance of Mandailing was also recognized by Harahap (2004a, 124-26), who notes that the Mandailing people were a large community that had been the centre of civilisation in North Sumatra before the entry of Islam to the region. This assertion was supported by Dutch researchers, who indicated that the Mandailing social and cultural structures were more developed than those of other Batak communities - i.e. the Toba, Simalungun, and Dairi (Sangti 1977, 46; Nasution 2001, 62; Harahap 2004a, 124; Lubis 2010, 1 \& 66; Perret 2010, 124; Nasution 2016, 4).

Several etymologies have been offered for the name mandailing. First, mandailing has been understood as derived from the word Mandalay, which is also linked to the word Myanmar (Nasution 2001, 63). Second, mandailing has been understood as derived from the words munda holing, referring to 
an Indian kingdom (Nasution 2016, 7-15). Third, it has been suggested that mandailing is derived from the word mandulang, meaning "to pan [for gold]". The Mandailing region has an abundance of gold, and in the past many people would pan for gold. Over time, this word shifted to become mandailing (Alam 2012, 24). Fourth, it has been proposed that the word mandailing is derived from mande ilang, meaning "mother is lost". It is this etymology, we propose, that makes the most sense. There are two versions of the Mande Ilang story. First, this phrase may have been derived from Mandailing's location on the border of the Minangkabau highlands, the inhabitants of which (the Minangkabau) are known for their matrilineal system. When Minangkabau migrants panned for gold in the region, their mothers 'disappeared' (Alam 2012, 24). In the second version, the Minangkabau migrants who settled in Mandailing gradually experienced cultural hybridity, transforming their matrilineal system into a patrilineal one (interview with traditional Mandailing leaders in Panyabungan on 24 July 2018, 11:0012:00). As Sangti explains, some residents of the Mandailing region come from elsewhere, and have voluntarily submitted to the patriarchal culture of the Mandailing (Sangti 1977, 50). It is this "loss of mothers" that some people suggest created the phrase mande ilang.

In this discussion, the word Mandailing refers to two things, namely the area / place and community / ethnic group. Furthermore, we identify community / ethnic groups with the word "people" (the same term used by Nasution in Mandailing Natal: Peluang, Tantangan, dan Harapan, 2001). As such, the term Mandailing may refer to either the region or the community group. The Mandailing people live in the Mandailing Natal Regency, which was created out of the South Tapanuli Regency through Law No. 12 of 1998 concerning the Establishment of the Toba Samosir Regency and Mandailing Natal Regency (State Gazette of the Republic of Indonesia of 1998 Number 188, Republic of Indonesia State Gazette Number 2437) and inaugurated by Interior Minister Syarwan Hamid on 9 March 1999 (Harahap 2004a, 13). Presently, the regency-with its capital in Panyabungan - consists of 23 districts, 377 villages, and 27 sub-districts. It covers 653.542 ha (Hanifah 2017, 3).

Historically, the Mandailing people have been open to others, as exhibited in their attitudes / behaviours and their everyday practices. This eased the creation of a new identity through what Bhabha terms hybridization, i.e. a cultural interface in Mandailing. Lubis (2003) states that the hybridisation of the Mandailing has been caused by several factors, namely Islamization, migration, and colonialism. Harahap adds that hybridisation occurred as the result of cultural contact, particularly the acculturation and assimilation of the Minangkabau and Batak Toba. Cultural interactions produced a hybrid of these two ethnic groups, which Harahap identifies as a smart and straightforward personality (Harahap 2004a, 128).

Such acculturation is also supported by the writings of Willem Iskander, who divides the Mandailing into several clans: 1) the Lubis clan, originally of Batak Toba heritage; 2) the Rangkuti clan, from Pagaruyung/Minangkabau; 3) the Nasution clan, from two different backgrounds - coastal people of various heritages who voluntarily submitted to patriarchal traditions (Dalihan $\mathrm{Na}$ Tolu) and a Batak person from Toba named Datu Nasangti Sibagot ni Pohan (Sangti 1977, 49-50).

Based on these views, the author has concluded that the hybridisation of the Mandailing people has been caused by several factors, including cultural contact and the influence of Islam, migration, and colonialism. These will be explored individually below. The main cause of hybridisation in Mandailing is cultural contact, as stated by Harahap:

Mandailing Natal Regency is a buffer zone between two communities with different kinship systems, namely the Batak Toba in North Tapanuli, who adhere to the patrilineal system, and the Minangkabau in West Sumatra, who adhere to the matrilineal system. The Batak Toba people still strongly practice the values of Batak culture; some remain animistic, and some are Christian. Meanwhile, the Minangkabau people have embraced Islam and adhere to Minangkabau traditions. There is a saying, adaik basandi syarak, syarak basandi Kitabullah, 
which highlights the determination of the Minangkabau people to practice Islamic teachings and traditional Minangkabau values" (Harahap 2004a, 127).

This quote highlights the encounter of two cultures in Mandailing Natal district, i.e. the Batak Toba and Minangkabau. The interactions of these cultures are influenced by two things, namely their customs / traditions and belief systems. The former includes different kinship systems (patrilineal and matrilineal), while the latter includes different faiths (animism and Islam).

Referring to Bhabha, in cultural encounters there exists a threshold space, called the twilight zone. In this threshold space, something "hybrid" emerges, something new, as a result of the combination of two different cultures. In this case, the hybrid form is the Mandailing, who have resulted from encounters between the Minangkabau and the Batak Toba and created a form of mimicry. As Bhabha 1994, 86) states, "colonial mimicry is the desire for a reformed, recognizable Other, as a subject of a difference that is almost the same, but not quite. The discourse of mimicry is construct around an ambivalence". This can be interpreted as showing that the purpose of mimicry is to be recognised by becoming a subject that is almost, but not completely, the same. This mimicry has created ambivalence among the Mandailing people.

Si Bulus-Bulus Si Rumbuk-Rumbuk describes mimicry in the belief and kinship systems of the Mandailing people, as follows. The literary work represents a belief system through the poems "Olo-Olo" and "Di Amateon Ni Boroe Na", as well as the prosaic pieces "Tiroean Ni Olong Ni Roa Marangka Maranggi" and "Na Binoewat Tingon Barita Ni Toewan Colombus". In both poems, the author still mentions God in the concept of tauhid (Islam), whereas in "Tiroean Ni Olong Ni Roa Marangka Maranggi" and "Na Bino Tingon Barita Ni Toewan Colombus", it refers to a concept of animism.

Both the poems "Olo-Olo" and "Di Amateon Ni Boroe Na" use the word Tuhan ("God"), referring specifically to the God of a monotheistic religion (i.e. Islam), the religion of the majority of Mandailing people. This differs from the prose "Tiroean Ni Olong Ni Roa Marangka Maranggi" and "Na Binoewat Tingon Barita Ni Toewan Colombus", which still refer to animist beliefs by using the word Debata. This can be seen in the following excerpts.

In the sixth verse of the poem "Olo-Olo", the author mentions the name of God, referring directly to the Islamic religion:

Ho dompak di anggoenan,
Abong ni malaikat manggobak ko,
Disoeroeon Toehan,
Di baon olong ni roa na di $o$.
Di sanggo oeroem moe na poso,
Di djagai ho sip so.
(Iskander, 1872, p. 14 )

When you are still swinging

Angel feathers cover you

God said

Because of His love for you

Kissed your young cheek

You, silent, calm guarded

(Iskander, 2002, p. 42

The word is used similarly in the second stanza of the poem "Di Amateon Ni Boroe Na", as seen below.

\begin{abstract}
Ale! oelang i sai tangisi, Ngada ija na matalpok;

Tai na ni pipil ni Toehan,
\end{abstract}

(Iskander, 1872, p. 15)
Dear! Don't cry for him

He did not fall

But was picked by God

(Iskander, 2002, p. 44)

Meanwhile, "Tiroean Ni Olong Ni Roa Marangka Maranggi" contains the sentence "Ngada sadia lolot, di leben Debata ma angoloean di alak na markantjiti" ("not long, God gives life to those who 
suffer) and "Na Binoewat Tingon Barita Ni Toewan Colombus" states "Ni pangidohon ma di debata oelang be ija laloe goesar" ("plead with God in order to hold His wrath)", indicating a belief in animism. Before Islam entered the region, the Mandailing people believed in traditional gods known as Debata Mulajadi Nabolon.

Through these excerpts, it is evident that an ambivalence was implicit in the Mandailing people's conceptual understanding of God. At the same time, drawing on beliefs that came originally from the Batak Toba, the Mandailing people acknowledged the presence of God as debata (animism) and recognition of Allah (the Mandailing people from Minangkabau). We understand the word God as referring to Allah for two reasons. First, when Si Bulus-Bulus Si Rumbuk-Rumbuk was written, Islam had already been embraced by the Mandailing people. Second, the author himself was Muslim.

In their current socio-cultural lives, the Mandailing are known as a religious people (Castles 2001, 18; Harahap 2004b, 32; Lubis 2010, 56). Islamic teachings influence every aspect of their lives. As a result, animist beliefs have been replaced by Islamic teachings, as Islam is practiced by almost all Mandailing people, who are known for their devotion. Islam, therefore, greatly influences their traditional ceremonies. During funerals and in inheritance rights, for example, Islamic law is more commonly used than customary law (Nasution 2016, 18-19).

Mimicry is also evidenced in the depiction of the Mandailing kinship system in Si Bulus-Bulus Si Rumbuk-Rumbuk, such as in the seventh paragraph of "Tiroean Ni Olong Ni Roa Marangka Maranggi".

"Di dokon angka na i ma: ,Torkis ko anggi! Ho ma ama ni pomparan $\boldsymbol{k}$ 'i, marsarak ma ita, oelang be aoe sai ambati. ,Tai ba ngada djaba't laloe songon giot níja $i$, di baon hoem giot di loempat ija dope toe laoet $i$, boeloes djong-djong ma anggi nîja $i$

tiboe tiboe, 'di sanggo ija angka nija i, bo di loempat ija boeloes toe laoeti: ,Mangoloe ho nijan angkang!" ning ija."

(Iskander, 1872, p. 24)
His brother said: "May you always stay healthy.

You are the father of my children. Be separate from us. Do not obstruct us anymore." But his will was not realised, because when he was about to jump into the sea, his younger brother came and embraced him. He jumped into the sea: "Live brother!," he said.

(Iskander, 2002, pp. 92-93)

In this quote, the author conveys that the Mandailing people adhered to a patrilineal kinship system, with lineage determined by one's father. A family's lineage will not be interrupted so long as there is a son. As the text shows, two male brothers can replace each other to continue their lineage. The word pomparan may be interpreted as "successor"; as such, a father will get pomparan or a successor if he has a son.

Note, then, the first verse of the poem "Di Amateon Ni Boroe Na":

\author{
Madoeng malongas sinoewan bojoe! \\ Moetik na poso madoeng madaboe, \\ ljetbo! Sial ni badan! \\ (Iskander, 1872, p. 14)
}

Has passed away my dear girl!

The young pistil has died

Oh! Unfortunate body!

(Iskander, 2002, p. 44)

In "Di Amateon Ni Boroe Na", the author denies the power of men by presenting women's power in his poetry. Through the word sinoewan ("girl") and phrase méctik na poso ("young pistil"), the author presents women as having power as successors. Although the author seems unsettled by this discourse, 
depicting the girl as dying in the poem ("Madung Malongas Sinoewan Bojoe"), the author nonetheless has shown that a female (matrilineal) power has influenced the culture of the Mandailing people.

Based on these quotations, ambivalence may be identified in the customs of the Mandailing people, particularly their kinship system, which simultaneously glorifies male power (patrilineal system) but also discusses women's power (matrilineal system). The creation of unequal relations is also an effect of the encounters between the Batak Toba (patrilineal) and Minangkabau (matrilineal).

Cultural hybridisation among the Mandailing, thus, is represented in the mimicry of the Mandailing people as seen in Si Bulus-Bulus Si Rumbuk-Rumbuk. Both the belief system and kinship system may be seen as ambivalent, indicating that there has indeed been a cultural transformation, as explained by Lubis in the quotation above.

Furthermore, the hybridisation of the Mandailing was also marked by the influence of Islam. This can be identified in the distribution of the Mandailing, predominantly found in the southern part of North Sumatra. As a result, the Mandailing people have had more intense interactions with the Minangkabau people than the Angkola people (before Mandailing was made its own regency, the Angkola and Mandailing shared an administrative district, namely South Tapanuli Regency; however, the Angkola people are culturally part of the Batak Toba / North Tapanuli). As such, it is not surprising that Islam's influence ultimately overwrote the animist / pagan beliefs that had previously been found among the Mandailing (Harahap 2004a, 149 \& 186).

In addition, the Mandailing people lost their clan identity, replacing it with an Islamic identity. However, they did not sever relations with local populations (Perret 2010, 171). As Castles $(2001,136)$ notes, by becoming Muslim, the southern Batak people, especially the Mandailing, found a new basis upon which they built their self-esteem.

The next factor is migration, which has contributed significantly to the hybridisation in Mandailing. As Castles explains $(2001,14)$, South Tapanuli has been more open to outside influences, and a number of similar clans in the region have migrated from the northern parts of Batak (Toba) territory. In other words, Castles emphasises, some Mandailing people trace their roots to North Tapanuli (Batak Toba).

Harahap and Siahaan state that the Mandailing people migrated due to regional conditions. Mandailing territory is located along two trade routes, where interactions and cultural contact allowed the emergence of hybridisation. Migration, thus, had a positive effect on the development of Mandailing discourse, as well as the local education system and economy. This mindset, Harahap and Siahaan argue, encouraged the Mandailing people to migrate (leave their hometowns) in hopes of obtaining better lives (Harahap and Siahaan 1987, 189).

Castles identifies the migration in Mandailing as part of 19th-century colonial politics. Massive migration from South Tapanuli to East Sumatra and the Malay peninsula, according to Castles, was intended to avoid forced labour. Castles also states that most migrants were farmers, traders, religious leaders, and the aides of Malay nobles. The vast majority were farmers, who sought agricultural land for farming. They travelled in three primary directions: to the south (Angkola), to the northwest (Dairi and Aceh), and to the northeast (Simalungun and Asahan; Castles 2001, 55). Migration certainly has significant potential to drive the creation of hybrid culture, as it involves several cultural elements. People from various social, with diverse levels of education, and social systems are involved in this activity.

Migration is represented in Si Bulus-Bulus Si Rumbuk-Rumbuk through "Adjar Ni Amang Na in $\mathrm{Na} \mathrm{Na}$ Kehe Toe Sikola", "Olo-Olo", "Oendan Dohot Oera-Oera", and "Si Baroar", as follows. 
The first stanza of the poem "Adjar Ni Amang Na, Na Kehe Toe Sikola" is shown as follows.

lljabo ale amang sinoewan toenas!

Longka ma ho amang mar goeroe toe sîkola;

Oelang hoem haen song loewas loewas

Tai ringgas ko amang mar sipoda.

(Iskander, 1872, p. 3)
Oh my dear child!

Just leave to go to school

Don't just play around

But diligently seek knowledge

(Iskander, 2002, p. 28)

In this quote, one factor driving the migration of the Mandailing is recorded. The author describes parents' wishes for children to leave their hometowns to seek knowledge by going to school. This desire for education, thus, is one factor that drove the Mandailing people to travel to other places.

The fourth verse of "Olo-Olo" also shows migration factors in Mandailing, as follows.

Moeda ho ma godang moese

Tartompoe ho ma toe djae toe djoeloe

Malo ma mandjama baenon, Olo inanang!

Na so oe parmoeda sajang!

Oe pala pe ho di portibi on.

(Iskander, 1872, p. 14)
When you grow up

You can roam anywhere

Also be smart at work

Yeah, my dear daughter!

Whom I don't waste!

I let you walk on this earth

(Iskander, 2002, p. 42)

In addition to presenting discourse on women's power (as discussed earlier), this poem also illustrates parents' wishes that their children can "toe djae toe djoeloe" (explore) and "oe pala pe ho di portibi on" (work and improve their lives). This indicates that, from an early age, parents instil their children with the desire to become nomads. This is also a cause of Mandailing migration.

The fourth verse of "Oendan Dohot Oera-Oera" is shown as follows:

\section{,Na denggan soeratan ni amporikon; \\ ,Sangombas tolap ma ija toe bariba, ,Hoem ahong na di irapkon, \\ ,Tolap ma ija tingon pastima toe poerba." \\ (Iskander, 1872, p. 32)}

"How good the bird's fate"

"The moment he arrived on the other side"

"Only his feathers flew"

"As he went from west to east"

(Iskander, 2002, p. 53)

This quotation indicates that the Mandailing migrate to improve their own lives, a desire that is derived from their recognition of the strength possessed by the people around them. This is reflected in the story of the turtle and bird above. The turtle considers the bird to have been blessed because it can fly and roam freely. Thus are the Mandailing people, whom the author interprets as amporik and oera. 
Finally, the eighth and twelfth stanzas of "Si Baroar" illustrate migration.

"Moeda na olong roa moe di anak moe $i$, lodjongkon ija gilo sannari. Dibaon moeda dapot oeloebalang ija, taoeken mate ma ija di tampoel kalai." ...

"Songon na mardjaot somba-somba ni si Saoewa i, di baon aha si Baroar i ma na mar karadjahan Soetan Aroe, na ma mompar na mora-mora di Mandailing on." (Iskander, 1872, p. 36)
"If you love your child, have him run now. Because if the commander sees him, he will definitely attack him. "

"Sauwa's worship was true, because the Baroar titled Sutan Aru took down the kings of Mandailing."

(Iskander, 2002, p. 77)

In this text, migration is depicted as having been caused by the tyranny of the king, who demands the death of Baroar. As such, Baroar must escape, as he is being pursued by a soldier who seeks to kill him. The words lodjongkan and na mora-mora confirm that migration events are caused by the repressive acts of authorities.

From this discussion, it can be seen that four factors are identified by Si Bulus-Bulus Si RumbukRumbuk as causing the migration of the Mandailing people, namely education, work, the desire for a better life, and tyranny. The factors causing hybridisation are also part of the Mandailing identity reflected in the text. As stated by Ashcroft, Griffiths, and Tiffin (2003, xxxiv), the migration process is one element of a deep anxiety regarding identity and authenticity in postcolonial literature. This is true also for Si Bulus-Bulus Si Rumbuk-Rumbuk.

Colonialism is the last factor in the hybridisation of the Mandailing discussed in this section. As mentioned previously, the Mandailing region experienced imperialism in its dealing with the Batak (Harahap 2004a, 149). This was followed by Dutch colonialism in the 19th century; the southern part of Tapanuli was the site of the first Dutch intervention in the archipelago, which began in 1833 (Perret 2010, 177).

The most pronounced hybridisation that occurred during the Dutch colonial era affected the government system. Colonial interference in customary governance was a milestone in the erasure of social stereotypes in the Mandailing community. The colonial government abolished the roles of kings / nobility among the Mandailing and reorganised traditional systems of governance. Traditional kings were reidentified as "Heads of Kuria" (Koeriahoofd). The reduction of their political authority had a significant psychological effect on the Mandailing people (Nasution 2001, 71-72; Nasution 2016, 101).

This implies that the Koeriahoofd government system is a form of Dutch colonial hegemony over the Mandailing people, undertaken to perpetuate Dutch colonial power and legitimise Dutch colonial power as superior to that of the Mandailing people. Stereotypes were deliberately built so that the Mandailing people would be confused when identifying themselves (i.e. as the self or the other).

In Si Bulus-Bulus Si Rumbuk-Rumbuk, the colonial government's intervention in the affairs of the Mandailing people is identified in the fourth paragraph of "Na Dangol Moeda Na So Binoto", as follows.

\begin{abstract}
"Di bagasan panga roa i ni radja itaoeken baon na adong ma i sala nija, oehoeman na ma i di baon toewan resident; tai na godang ma lakna asalahan nija $i$, dibaon dengganan dope ija tarkoeroeng salapan ari oempado manginoem aëk milas-milas songon $i$, poelik madoeng gonong di lala ija boltok nija."
\end{abstract}

(Iskander, 1872, p. 16)
In the king's heart, he was certain that he had been guilty. This was a punishment given by the resident. It seemed to be a big mistake, because he felt better locked up for eight days than drinking hot water like that. His stomach already felt inundated.

(Iskander, 2002, p. 101) 
"Na Dangol Moeda Na So Binoto" described the unequal power between the king (Mandailing) and resident (Dutch colonial leader). Although the king should have had the respect of his people, he was under the colonial government. The quote describes the king as a person who deserves the blame and punishment of the colonial government. As such, colonialism greatly affected the Mandailing system of government. The monarchy was transformed to suit the interests of the colonial government.

The power relation in each of the factors causing hybridization in the Mandailing socio-cultural system shows the form of identity negotiation. Identity struggles have continued to occur within the social system that has become the communal ideology of the Mandailing people. Cultural hybridisation has provided a means of negotiating the identity of each tribe in Mandailing. As Bhabha argues, the question of identity is complex, ambivalent, and contradictory. For Bhabha, there is no "authentic" or "singular" identity. Bhabha also explains that it is impossible for power relations to operate without ambivalent attribution (Bhabha 1994, 67-70). As such, the Mandailing people will continue to negotiate as they form new power relations.

\section{Conclusion}

Hybridization in Mandailing is seen through the cultural contact, Islamic influence, migration and colonialism which continuously exist reciprocally. Then, it lead to the ambivalence of the Mandailing people. The ambivalence results their identity instability in the social life. The ambivalence arising from the hybridization belongs to the result of Mandailing negotiations. It is reflected in the ongoing identity ambivalence of the people. This ambivalence is seen through the attitude of the Mandailing people who obey the colonial culture at a certain time, but they discourage the resistance. Through a postcolonial paradigm, the text of Willem Iskander's Si Bulus-Bulus Si Rumbuk-Rumbuk succeeded in exposing another side of Mandailing identity.

\section{Acknowledgement}

Thank you to the Directorate of Research and Community Service, the Directorate General of Research and Development Strengthening, and the Ministry of Research, Technology and Higher Education who have contributed to this research. in the acknowledgment sheet.

This article has been prepared as part of a dissertation titled "The Text of Si Bulus-Bulus Rumbuk-Rumbuk by Willem Iskander: A Postcolonial Review." This dissertation is dedicated to Medan State University, North Sumatra. The author is currently pursuing a doctoral degree in the humanities at the Faculty of Cultural Sciences, Gadjah Mada University, Yogyakarta, Indonesia, with the advisors Prof. Faruk and Dr. Aprinus Salam. Thank you to the Directorate of Research and Community Service, the Directorate General of Research and Development Strengthening, and the Ministry of Research, Technology and Higher Education who have contributed to this research. 


\section{References}

Agustono, B., \& Junaidi. (2018). "The Dutch Colonial Economic Policy: Coffee Exploitation in Tapanuli Residency, 1849-1928." Kemanusiaan, 2(2), 49-69.

Alam, S. T. (2012). Surat Tumbaga Holing I: Buku Pelajaran Adat Tapanuli Selatan. Medan: Mitra.

Ashcroft, B., Griffiths, G., \& Tiffin, H. (2003). Menelanjangi Kuasa Bahasa: Teori dan Praktik Sastra Poskolonial. Yogyakarta: Qalam.

Barker, C. (2008). Cultural Studies: Teori \& Praktik. Yogyakarta: Kreasi Wacana.

Bhabha, H. K. (1994). The Location of Culture. London and New York: Routledge.

Castles, L. (2001). Kehidupan Politik Suatu Keresidenan di Sumatera: Tapanuli 1915-1940. Jakarta: KPG.

Day, T., \& Foulcher, K. (2008). Bahasan Postkolonial dalam Sastra Indonesia Modern. In Sastra Indonesia Modern: Kritik Postkolonial (pp. 1-23). Jakarta: Obor Indonesia.

Foucault, M. (1972). The Archaeology of Knowledge. New York: Routledge.

Hall, S. (1997). "Representation: Cultural Representations and Signifying Practices". In The Work of Representation (pp. 15-64). London: Sage Publications.

Hanifah, A. (2017). Data Dasar Ekonomi Kabupaten Mandailing Natal Tahun 2017. Panyabungan.: Pemerintah Kabupaten Mandailing Natal Badan Perencanaan Pembangunan Daerah.

Harahap, B. H. (2004). Madina yang Madani. Panyabungan: Pemerintah Daerah Kabupaten Madina.

Harahap, B. H., \& Siahaan, H. M. (1987). Orientasi Nilai-Nilai Budaya Batak: suatu Pendekatan Terhadap Perilaku Batak Toba dan Angkola-Mandailing. Jakarta: Sanggar Willem Iskander.

Harahap, M., Faruk, F., \& Salam, A. (2019a). "Si Bulus-Bulus Si Rumbuk-Rumbuk sebagai Teks yang Hegemonik." Atavisme, 22(1), 88.

Harahap, M., Faruk, \& Salam, A. (2019b). "Racism in Mandailing Literature: Postcolonial Discourse." The 28th International Conference on Literature, 246-253. Banda Aceh: Syiah Kuala University Press.

Iskander, W. (1872). Si Boeloes-Boeloes, Si Roemboek-Roemboek: Sada Boekoe Basaon. Batavia: Landsdrukkerij.

Iskander, W. (2002). Si Bulus-Bulus Si Rumbuk-Rumbuk: Dwi Bahasa Pengantar dan Terjemahan Basyral Hamidy Harahap. Jakarta: Sanggar Willem Iskander.

Lubis, A. (2003). "Transformation of Mandailing Cultural Identity and Leadership". Journal of the Malaysian Branch of the Royal Asiatic Society, 55-79.

Lubis, ZP. (2010). Kumpulan Catatan Lepas tentang Mandailing. Medan: Pustaka Widiasarana.

Nasution, P. (2001). Mandailing Natal: Peluang, Tantangan dan Harapan. Medan: Yayasan Parsarimpunan Ni Tondi. 
Nasution, P. (2016). Mandailing dan Adatnya. Mandailing Natal: Pencerahan Mandailing.

Perret, D. (2010). Kolonialisme dan Etnisitas Batak dan Melayu di Sumatera Timur Laut. Jakarta: KPG (Kepustakaan Populer Gramedia).

Rodgers, S. 2005. "Compromise and Contestation in Colonial Sumatra: An 1873 Mandailing Schoolbook on the 'Wonders of the West'." Bijdragen tot de Taal-, Land- en Volkenkunde 158(3): 479-512.

—. 2007. "Narrating 'the modern': Colonial-era Southern Batak Journalism and Novelistic Fiction Asoverlapping Lliterary Forms." Bijdragen tot de Taal-, Land- en Volkenkunde 163(4): 476-506.

Said, E. (1994). Orientalisme (Diterjemahkan oleh Asep Hikmat dari Orientalism). Bandung: Pustaka.

Sangti, B. (1977). Sejarah Batak. Balige: Karl Sianipar Company.

Siregar, K., Djono, D., \& Sutimin, L. A. (2018). The Implementation of Willem Iskandar's Thought in the Historical Learning. International Journal of Multicultural and Multireligious Understanding, 5(3), 234-245. https://doi.org/10.18415/ijmmu.v5i3.346.

\section{Copyrights}

Copyright for this article is retained by the author(s), with first publication rights granted to the journal.

This is an open-access article distributed under the terms and conditions of the Creative Commons Attribution license (http://creativecommons.org/licenses/by/4.0/). 